\title{
HUBUNGAN CITRA MEREK MAJALAH GADIS DENGAN LOYALITAS MEMBACA MAJALAH GADIS DI KOTA SEMARANG
}

\author{
Ahmad Khairul Nuzuli \\ Magister Ilmu Komunikasi, FISIP, UNDIP \\ ahmad.nuzuli@gmail.com
}

\begin{abstract}
$T$

his study examines the Correlation between brand image Gadis Magazine with loyalty of reading Gadis Magazine in Semarang city. Rationale informing the research this is the Expectancy Value Theory States that the person's behavior is a function of the value the results expected of a deed. The person's behavior will result in something, the higher the expected value, the higher the desire to realize a particular behaviours. Paradigm in this research is positivistic. This research is classified in explanative type of research. The population in this research is 425 students of Senior High School 1 Semarang, in 10th grade dan have known to read Girl Magazines. This research using multistage random sampling technique, taken a sample of 136 students. The results of the calculation of the correlation Statistics Kendall's Tau B between brand image Gadis Magazine with loyalty of reading Gadis Magazine in Semarang city, retrieved the significance of 0.018 or smaller than the critical numbers i.e. 0.05. So that there is a correlation between the two variables in this research by demonstrating significant results. If viewed from the coefficients of Correlation obtained results 1.0. It can be noted that the relationship is very high.
\end{abstract}

Keywords : Brand Image; Loyalty Of Reading; Gadis Magazine.

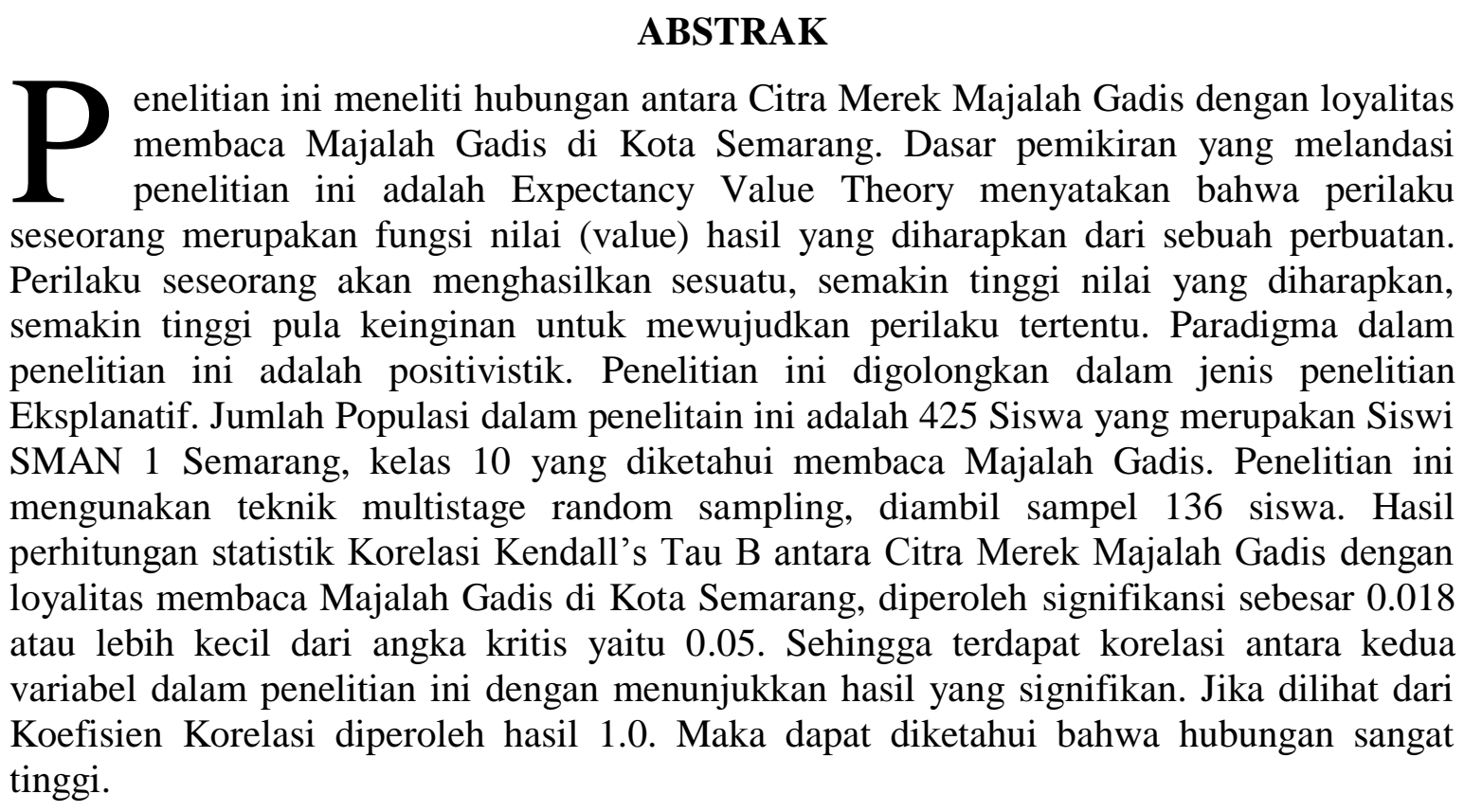

Kata kunci : Citra Merk; loyalitas Membaca; majalah gadis.

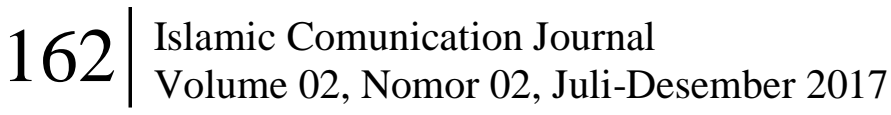




\section{PENDAHULUAN}

Majalah ialah salah satu bentuk media massa yang disajikan dalam bentuk cetakan, dengan berbagai rubrik yang berisi gagasan feature serta artikel dan gambar yang terkandung di dalamnya, untuk kemudian dipublikasikan secara berkala (Wardhani 2008, 30-31).

Sebagai salah satu jenis majalah remaja, Majalah Gadis yang didirikan oleh Femina Group sejak tahun 1973 ini, memiliki cakupan distribusi hingga ke seluruh Indonesia dengan target audience usia 13-19 tahun. Majalah Gadis mampu bertahan dan bersaing dengan kompetitornya sesama majalah remaja, baik yang berskala lokal maupun nasional. Brand Majalah Gadis bahkan mampu menempatkan diri sebagai brand majalah remaja yang paling banyak dibaca di Indonesia (Sumber : http:// www.gadis.co.id/tentang-gadis/ diakses pada 25 Februari 2017) .

Hal itu dibuktikan oleh hasil survey yang dilakukan oleh Frontier Consulting Group, Majalah Gadis mendapatkan gelar Top Brand untuk sub kategori majalah pada kategori Top Brand For Teens selama lima tahun berturut-turut dari tahun. Data survey tersebut adalah sebagai berikut :

TABEL 1.1 Survey Top Brand Award Tahun 2012-2016

(Top Brand For Teens - Majalah Remaja)

\begin{tabular}{|c|c|c|c|c|c|c|c|c|}
\hline \multicolumn{2}{|c|}{2012} & \multicolumn{3}{c|}{2013} & \multicolumn{3}{c|}{2014} \\
\hline Merek & TBI & TOP & Merek & TBI & TOP & Merek & TBI & TOP \\
\hline GADIS & $\mathbf{3 9 , 7 \%}$ & TOP & GADIS & $\mathbf{4 1 , 1 \%}$ & TOP & GADIS & $\mathbf{2 7 , 2 \%}$ & TOP \\
\hline Aneka & $14,9 \%$ & TOP & Aneka & $11,1 \%$ & TOP & Aneka & $19,9 \%$ & TOP \\
\hline Hai & $11,0 \%$ & TOP & Hai & $9,6 \%$ & & Hai & $17,3 \%$ & TOP \\
\hline Motor plus & $6,6 \%$ & & Kawanku & $8,1 \%$ & & Kawanku & $10,5 \%$ & \\
\hline
\end{tabular}

\begin{tabular}{|c|c|c|c|c|c|}
\hline \multicolumn{3}{|c|}{$\mathbf{2 0 1 5}$} & \multicolumn{3}{|c|}{$\mathbf{2 0 1 5}$} \\
\hline Merek & TBI & TOP & Merek & TBI & TOP \\
\hline GADIS & $\mathbf{3 5 , 5 \%}$ & TOP & GADIS & $\mathbf{3 6 , 8 \%}$ & TOP \\
\hline Aneka & $16,3 \%$ & TOP & Aneka & $17.7 \%$ & TOP \\
\hline Hai & $15,2 \%$ & TOP & Hai & $9,9 \%$ & \\
\hline Go Girl & $10,5 \%$ & & Cosmo Gi & $4,5 \%$ & \\
\hline
\end{tabular}


(Sumber : http://www.topbrand-award.com/top-brand-survey/survey-

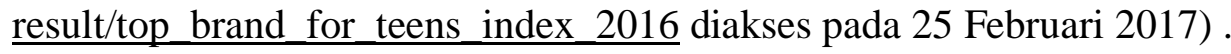

TBI dinyatakan sebagai Top Brand ketika angka persentasenya minimal $10 \%$. Kemudian merujuk pada tabel diatas, angka TBI Majalah Gadis jauh melampaui angka 10\%, maka dari itu Majalah Gadis dapat digolongkan ke dalam Top Brand pada Kategori Majalah Remaja. Angka presentase yang didapatkan Majalah Gadis pada tahun 2012 sebesar 39,7 \%, tahun 2013 sebesar 41,1\%, tahun 2014 sebesar 27,2\%. Tahun 2015 sebesar 35,5\%, dan pada tahun 2016 sebesar $36.8 \%$. Merek-merek yang mendapatkan gelar Top Brand dari survey tersebut bersifat independen dikarenakan murni atas pilihan konsumen, dimana parameter pengukurannya berdasarkan kualitas produk, inovasi pembangunan merek, dan pembangunan hubungan dengan konsumen. Hasilnya pun dipublikasikan secara luas lewat Majalah Marketing. Merek tersebut harus terpilih oleh konsumen melalui hasil survey dengan melihat tiga parameter yakni top of mind share, top of market share dan top of commitment share (Sumber: http://www.topbrand-award.com /faq diakses pada 25 Februari 2017).

Top Brand merupakan hasil pilihan konsumen dan merek-merek yang meraih Top Brand memang terbukti merek-merek yang juara di kategorinya. Survey Top Brand sudah berlangsung sejak 14 tahun yang lalu, jadi merupakan survei yang sudah lama hadir di Indonesia. (Sumber : http://www.topbrand-award.com/faq diakses pada 25 Februari 2017).

Gelar brand berkualitas yang didapatkan oleh sebuah merek atas penghargaan Top Brand tersebut sendiri juga diukur dari beberapa parameter seperti :

○ Quality Before Price : Perusahaan yang memiliki Top Brand adalah perusahaan yang dipimpin oleh jajaran manajemen yang percaya akan pentingnya kualitas, baik kualitas produk atau kualitasl ayanan, tergantung dari industry dimana mereka berada di dalamnya

○ Innovation Before Cost : Dengan perubahan pasar yang dinamis terutama perubahan perilaku konsumen dan pelanggan, hanya perusahaan yang selalu mengedepankan inovasi yang mampu membangun merek yang kuat

○ Engagement Before Sales : Perusahaan pemenang Top Brand ini, memiliki paradigma yang kuat 
bahwa bisnis haruslah didasarkan atas relationship dan bukan transaksional (Sumber:

http://www.frontier.co.id/3-rulesof-success-in-building-top-brand. html diakses 28 Februari 2017 )

Ketiga faktor tersebut berhasil dilaksanakan oleh Majalah Gadis, karena dapat dilihat majalah khusus remaja cewek di Indonesia ini selalu duduk di peringkat atas pada survey Top Brand. Hasil dari survey Top Brand ialah akurat baik dalam segi kualitas brand itu sendiri, yang juga berbanding lurus dengan tingkat penjualan serta minat dan loyalitas penggunaan masyarakat terhadap brand itu sendiri. Hal ini pun berlaku bagi Majalah Gadis yang selama 3 tahun berturut-turut menjadi merek paling top pada survey tersebut. Dampaknya pada pembaca terletak pada bagaimana loyalitas mereka dalam membaca Majalah Gadis, berbanding lurus dengan kualitas yang dihadirkan Majalah Gadis sehingga membuat citra mereknya positif.

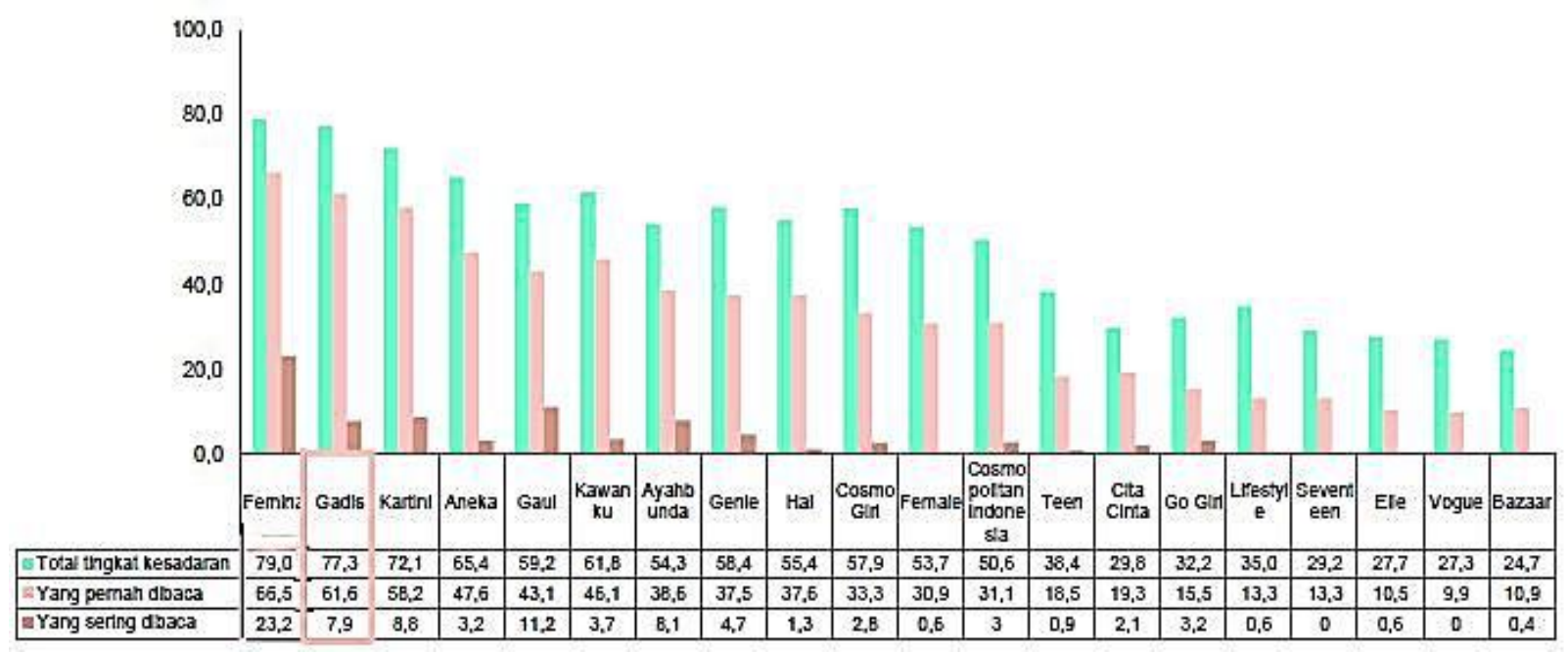

Tabel 1.2 Survey Tingkat Kesadaran Seseorang dalam Membeli Majalah Wanita 2013

Sumber : PT. Nusaresearch (http://nusaresearch.com) 2013

Kemudian berdasarkan hasil survey lain, Majalah Gadis menjadi satu-satunya majalah Remaja yang menduduki peringkat kedua dalam Survey Tingkat Kesadaran Seseorang dalam Membeli Wanita yang dilakukan oleh Nusa Research tahun 2013 dengan Total persentasie tingkat kesadaran yang diukur dengan pertanyaan mengenai merek majalah

wanita yang diketahui sebesar 77,3\%. Kemudian Total persentase Majalah yang Pernah Dibaca sebesar 61,6\%, terakhir Total persentase Majalah yang Sering Dibaca sebesar 7,9\%. ( Sumber : http://nusaresearch.com diakses pada 28 Februari 2017) . 
Namun, hal-hal diatas ternyata tidak lantas menjadikan Majalah Gadis sebagai satu-satunya penguasa pasar. Merujuk pada 2 hasil survey yaitu Top Brand Award dan Nusa Research, ada dua nama Majalah Remaja yang tepat berada di bawah Gadis yaitu Aneka dan Hai. Majalah Aneka dan Hai adalah dua nama majalah Remaja yang telah sejak lama dikenal masyarakat. Majalah Aneks pertama kali terbit pada awal tahun 1990-an, sedangkan Majalah Hai adalah majalah pria pertama yang terbit di Tahun 1977 dibawah naungan nama besar Arswendo Atmowiloto. Segmentasi Majalah Aneka dan Hai tidak jauh berbeda dengan Majalah Gadis yaitu remaja usia 13-25 tahun (25 tahun khusus untuk Majalah Hai), jangkauan distribusinya pun juga seIndonesia. Dari segi konten yang dihadirkan, Majalah Aneka dan Hai tidak jauh berbeda dengan Majalah Gadis yaitu seputar dunia Remaja seperti fashion, lifestyle, cinta, musik, tips, zodiac, selebriti dll. Majalah Aneka memilki rubrik interaksi khusus dimana pembaca bisa mengirimkan gambar yang akan di analisis seorang atau graphologist. Kemudian, Majalah Hai sejak dahulu, selalu menerbitkan rubrik-rubrik cerita serial menarik yang melahirkan cerita besar seperti Balada Si Roy ciptaan Novelis Gol A Gong lalu Serial Lupus ciptaan Hilman Hariwijaya (Sumber: http://www.anneahira.com / majalah-hai.htm diakses pada 27 Februari 2017) .

Membahas mengenai harga, kedua majalah tersebut lebih murah dibandingkan harga Majalah Gadis yaitu Rp 20.000 - Rp 45.000,- (edisi special atau edisi ulang tahun biasanya lebih mahal). Harga Majalah Aneka adalah Rp 20.000 sedangkan Majalah Hai hanya berkisar Rp 10.000. Kompetitor lain sesama majalah remaja antara lain, Go Girl, Kawanku, Top Teen, dan Cosmo Girl. Majalah-majalah tersebut sama-sama memiliki segmen Remaja, khususnya Remaja putri.

Meskipun demikian persaingan majalah-majalah tersebut dengan Majalah Gadis tidak terlalu ketat terutama di Jawa Tengah. Rata-rata penjualan Majalah Gadis tiap bulannya di seluruh wilayah di Indonesia ialah sebesar 150.000 kopi, dan sekitar 5\% dari jumlah tersebut atau sejumlah 7.500 kopi terjual di wilayah Jawa Tengah dan sekitarnya (Sumber

http://www.feminagroup.com/media.kit/001/ $\underline{2}$ diakses pada 19 Februari 2017).

.Hal tersebut memiliki kaitan erat dengan citra merek Majalah Gadis itu sendiri dimana citra merek bisa terbentuk dari interaksi merek atau brand dengan konsumennya. Menurut Runyon (1980: 17), citra merek terbentuk dari stimulus tertentu yang ditampilkan oleh produk tersebut, yang menimbulkan respon tertentu pada diri 


\section{Ahmad Khairul Nuzuli}

konsumen. Stimulus yang muncul dalam citra merek tidak hanya terbatas pada stimulus yang bersifat fisik, tetapi juga mencakup stimulus yang bersifat psikologis. Stimulus-stimulus tersebut bisa berasal dari komponen yang berasal dari merek itu sendiri.

Namun, menjadi majalah yang banyak dibaca bahkan mendapat gelar Top Brand di dalam sasaran pemasaran mengalahkan sejumlah industri majalah lain selama bertahun-tahun tidaklah cukup. Faktanya dalam TBI atau Top Brand Index yang disajikan Survey Top Brand Award, TBI dari Majalah Gadis terlihat fluktuatif atau naik turun dari tahun 2012 hingga ke tahun 2016 yaitu sebesar 39,7 \% pada tahun 2012, kemudian naik sebesar $41,1 \%$ pada tahun 2013, dan mengalami penurunan cukup tajam pada tahun 2014 sebesar 27,2\%, lalu mengalami sedikit kenaikan 2015 sebesar 35,5\%, dan pada tahun 2016 sebesar $36.8 \%$ .Meskipun kedua pesaingnya Majalah Aneka dan Hai juga cukup fluktuatif, namun majalah-majalah tersebut berpotensi menggeser posisi Majalah Gadis sebagai Top Brand nomor 1, keadaan tersebut dikarenakan pada tahun terakhir survey 2014 Majalah Aneka mendapat perolehan angka sebesar 19,9\% dan Majalah Hai sebesar $17,3 \%$, dua angka yang tidak terlalu jauh dari perolehan Majalah Gadis. Disaat Majalah Gadis mengalami penurunan cukup tajam pada tahun 2014, kedua pesaingnya justru mengalami kenaikan cukup pesat pada tahun yang sama.

Dari sekian banyak faktor yang mempengaruhi posisi Majalah Gadis yang selalu fluktuatif tersebut, bisa juga dikarenakan keinginan dari dalam diri pembaca tersebut apakah ingin membaca ulang lagi Majalah Gadis atau tidak dengan segenap alasan yang dimilikinya. Istilah yang akrab dengan konteks tersebut ialah loyalitas. Yang dimaksud dengan loyalitas pelanggan secara umum dapat diartikan sebagai kesetiaan seseorang suatu barang atau jasa tertentu. Loyalitas pelanggan merupakan manifestasi dan kelanjutan dari kepuasan konsumen walaupun tidak mutlak merupakan hasil kepuasan konsumen. Loyalitas mempunyai pola pembelian ulang pada merek fokal yang merupakan loyalitas sesungguhnya atau loyalitas pada merek tunggal. Sehingga loyalitas pelanggan disini dapat diartikan sebagai loyalitas merek (Hasan, 2008:81)

Meskipun Majalah Gadis tetap berada di urutan pertama, namun bukan tidak mungkin jika terus mengalami penurunan, maka industri majalah pesaing akan dapat melampaui posisi Majalah Gadis saat ini sebagai merek paling diketahui oleh khalayak dan pada akhirnya akan berimbas pada loyalitas pembaca yang membaca Majalah Gadis bisa menurun. Berdasarkan fakta diatas, apakah ada hubungan antara 
citra merek Majalah Gadis dengan loyalitas membaca Majalah Gadis di Kota Semarang?

\section{TINJAUAN PUSTAKA}

\section{Citra Merk}

Citra merek dapat didefinisikan sebagai suatu persepsi yang muncul di benak konsumen ketika mengingat suatu merek dari produk tertentu. Asosiasi Pemasaran Amerika mendefinisikan merek (brand) sebagai nama, istilah, tanda, simbol, atau rancangan, atau kombinasi dari semuanya, yang dimaksudkan untuk mengidentifikasikannya dari barang atau jasa pesaing (Kotler, 2005: 332). Bagi pembeli, merek bermanfaat menceritakan mutu dan membantu memberi perhatian terhadap produk - produk baru yang mungkin bermanfaat bagi mereka. Bagi penjual, merek bermanfaat dalam empat hal. Pertama, memudahkan penjual mengolah pesan dan menelusuri masalah - masalah yang timbul. Kedua, memberikan perlindungan hukum atas keistimewaan produk. Ketiga, memungkinkan untuk menarik sekelompok pembeli yang setia dan menguntungkan. Keempat, membantu penjual melakukan segmentasi pasar.

Produsen atau pemilik produk harus bisa memberikan merek pada pada barang yang akan dijualnya. Merek inilah yang menjadi identitas produk dan secara jelas membedakan antara produk satu dengan produk yang lain. Oleh karena itu, merek merupakan komponen penting. Merek Juga digunakan untuk membangun citra dibenak konsumen, baik positif atau negatif.

Citra adalah total persepsi terhadap suatu objek yang dibentuk dengan memproses informasi dari berbagai sumber setiap waktu. Citra merek adalah jumlah dari gambaran - gambaran, pesan - pesan, dan keyakinan - keyakinan yang dimiliki seseorang terhadap suatu merek (Sustisna,2002:199). Citra merek (brand image) dapat dianggap sebagai jenis asosiasi yang muncul dibenak konsumen ketika mengingat sebuah merek tertentu. Asosiasi tersebut secara sederhana dapat muncul dalam bentuk pemikiran atau citra tertentu yang dikaitkan kepada suatu merek, sama halnya ketika kita berfikir tentang orang lain. Asosiasi ini dapat dikonseptualisasi berdasarkan: jenis, dukungan, kekuatan, dan keunikan (Shimp, 2003: 12).

Menurut Arafah (2004:61) citra adalah realitas, oleh karena itu program pengembangan dan perbaikan citra harus didasarkan pada realitas. Jika citra tidak sesuai dengan realitas itu kan mempengaruhi keyakinan atau kepercaan bahkan loyalitas terhadap produk tersebut dalam hal ini loyalitas membaca Majalah Gadis. Citra yang baik merupakan hasil dari Merek tersebut dalam memberikan pelayanan yang mampu memuaskan konsumen dalam hal ini pembaca. 


\section{Ahmad Khairul Nuzuli}

Pengertian Citra berdasarkan Buchari Alma dalam bukunya Manajemen Pemasaran dan Manajemen Pemasaran Jasa, adalah kesan yang diperoleh sesuai dengan pengetahuan dan pengalaman sesorang terhadap sesuatu (Alma, 2005 : 12). Definisi Citra Merek berdasarkan Ouwersoot dan Tudorica adalah Kumpulan persepsi tentang sebuah merek yang saling berkaitan yang ada dalam pikiran manusia. (Ouwersoot, 2001:45).

Dalam jurnal Conceptualizing, Measuring, and Managing Customer-Based Brand Equity, Keller (1993) menyatakan bahwa citra merek yang positif atau negatif terjadi ketika konsumen memberikan reaksi yang baik atau kurang baik terhadap atribut tertentu dari suatu merek. Keller, dkk (2009:4) juga menyatakan citra merek terdiri dari tiga unsure yaitu attributes, benefits dan attitude. Yang dimaksud dengan atribut adalah hal-hal yang berkaitan dengan merek tersebut,seperti kemasan dan tampilan, harga, informasi produk, dan isi produk. Sementara benefits berarti keuntungan atau nilai-nilai yang dikaitkan oleh konsumen pada atribut produk atau jasa. Dan yang terakhir adalah brand attitude yang merupakan evalusasi suatu mereka yaitu apa yang dipercayai oleh konsumen mengenai merek-merek tertentu.

Sedangkan menurut Kotler (2005:226) brand image (citra) adalah kumpulan keyakinan atau kepercayaan atas merek/ brand tertentu. Kepercayaan masyarakat kepada suatu produk dalam hal ini Merk Majalah Gadis. Citra tergantung kepada bagaimana masyarakat memandang Majalah Gadis. citra sebuah produk dapat dibentuk dengan beragam cara dan strategi, salah satunya konstruksi media.

Menurut Rakhmat (2013 : 222) Citra terbentuk berdasarkan informasi yang diterima. Media massa bekerja untuk menyampaikan informasi bagi khalayak. Informasi dapat membentuk dan mempertahankan atau mendefinisikan citra. Proses kognitif bertujuan untuk menjelaskan bagaimana informasi eksternal diberi pemakanaan menjadi sebuah pemikiran dan penilaian.

Citra merek umumnya didefinisikan segala hal yang terkait dengan merek yang ada dibenak ingatan konsumen. Citra merek merepresentasikan keseluruhan persepsi konsumen terhadap merek yang terbentuk karena informasi dan pengalaman konsumen terhadap satu merek (Suryani, 2008: 113).

Menurut Ginting (2011:99) mendefinisikan merek adalah suatu nama, istilah, tanda, simbol, desain atau kombinasi daripadanya untuk menandai produk atau jasa dari satu penjual atau kelompok penjual dan untuk membedakannya dari pesaing.

Berdasarkan definisi di atas, dapat disimpulkan bahwa citra merek merupakan nama, istilah, simbol, tanda, dan desain yang 
digunakan oleh perusahaan untuk membedakan produk dengan para pesaing.

Menurut Tjiptono (2011:43) merek juga memiliki manfaat yaitu bermanfaat bagi produsen dan konsumen. Bagi produsen, merek berperan penting sebagai:

a. Sarana identifikasi untuk memudahkan proses penanganan atau pelacakan produk bagi perusahaan, terutama dalam pengorganisasian sediaan dan pencatatan akuntansi.

b. Bentuk proteksi hukum terhadap fitur atau aspek produk yang unik. Merek bisa mendapatkan perlindungan properti intelektual. Nama merek bisa diproteksi melalui merek dagang terdaftar (registered trademarks) proses pemanufakturan bisa dilindungi melalui hak paten dan kemasan bisa diproteksi melalui hak cipta (copyright) dan desain.

c. Signal tingkat kualitas bagi para pelanggan yang puas, sehingga mereka bisa dengan mudah memilih dan membelinya lagi di lain waktu.

d. Sarana untuk menciptakan asosiasi dan makna unik yang membedakan produk dari para pesaing.

e. Sumber keunggulan kompetitif, terutama melalui perlindungan hukum, loyalitas pelanggan, dan citra unik yang terbentuk dalam benak konsumen. f. Sumber financial returns, terutama menyangkut pendapatan masa datang.

Bagi konsumen, merek bisa memberikan beraneka macam nilai melalui sejumlah fungsi dan manfaat potensial. Menurut Sunyoto (2012:103), menjelaskan bahwa pemberia nama merek atas suatu produk menjadi sangat penting dan mempunyai manfaat, antara lain:

1. Bagi Konsumen

Manfaat nama merek suatu produk bagi konsumen di antaranya:

- Mempermudah konsumen meneliti produk atau jasa. Untuk merekmerek produk yang sudah terkenal dan mapan, konsumen seolah sudah menjadi percaya, terutama dari segi kualitas produk.

- Membantu konsumen atau pembeli dalam memperoleh kualitas barang yang sama, jika mereka membeli ulang serta dalam harga.

2. Bagi Penjual

Manfaat nama merek suatu produk bagi penjual di antaranya:

- Nama merek memudahkan penjualan untuk mengolah pesananpesanan dan menekan permasalahan. 


\section{Ahmad Khairul Nuzuli}

- Merek juga akan membantu penjual mengawasi pasar mereka karena pembeli tidak akan menjadi bingung.

\section{Loyalitas}

Secara harfiah loyal berarti setia, atau loyalitas dapat diartikan sebagai suatu kesetiaan. Kesetiaan ini diambil tanpa adanya paksaan, tetapi timbul dari kesadaran sendiri pada masa lalu. Usaha yang dilakukan untuk menciptakan kepuasan konsumen lebih cenderung mempengaruhi sikap konsumen. Sedangkan konsep loyalitas konsumen lebih menerangkan kepada perilaku pembelinya. Komitmen yang menyertai pembelian berulang tersebut adalah keadaan dimana konsumen tidak mau berpindah walaupun produk maupun jasa tersebut sedang langka dipasaran dan konsumen dengan sukarela merekomendasikan produk maupun jasa tersebut kepada rekan, keluarga atau konsumen yang lain.

Loyalitas merek dalam hal ini kaitannya dengan Majalah Gadis, menurut Ali Hasan adalah kecenderungan konsumen untuk membeli sebuah merek tertentu dengan tingkat konsistensi yang tinggi dikarenakan kepuasaan konsumen yang didapat dari merek tertentu. (Hasan, 2008:81)

Mernurut Griffin (2002) mengatakan "loyality is defined as non random purchase expessed over time by some decision making unit". Arinya loyalita lebih dimaksudkan sebagai perilaku mengkomsumsi rutin didasarkan keputusan. Dalam penelitian ini hal tersebut bisa dihubungkan dengan perilaku mengkonsumsi dengan cara loyalitas membaca Majalah Gadis.

Menurut Hermawan (2003 :126) loyalitas adalah sebuah bentuk kebutuhan manusia dalam hal ingin memiliki, mensupport, mendapat rasa aman serta membangun ketertarikan serta menciptakan emotional attacment. Perasaan tertarik inilah yang menjadi unsur utama yang membangun loyalitas konsumen yang dalam hal ini kosumen majalah gadis untuk loyal dalam hal mengkonsumsi dengan cara membaca.

Menurut Rangkuti,Freddy (2002:60), Loyalitas konsumen adalah kesetiaan konsumen terhadap perusahaan, merek maupun produk. Sutisna (2003:41) mendefinisikan loyalitas adalah sikap menyenangi terhadap suatu merek yang dipresentasikan dalam pembelian yang konsisten terhadap merek itu sepanjang waktu. Menurut Tjiptono (2004:110), loyalitas konsumen adalah komitmen pelanggan terhadap suatu merek, toko atau pemasok berdasarkan sifat yang sangat positif dalam pembelian jangka panjang. Dari pengertian ini dapat diartikan bahwa kesetiaan terhahadap merek diperoleh karena adanya kombinasi dari kepuasan dan 
keluhan. Sedangkan kepuasan pelanggan tersebut hadir dari seberapa besar kinerja perusahaan untuk menimbulkan kepuasan tersebut dengan meminimalkan keluhan sehingga diperoleh pembelian jangka panjang yang dilakukan oleh konsumen. Hal ini bisa diartikan konsumen atau pembaca Majalah Gadis akan secara konsisten melakukan pembelian dan membaca Majalh Gadis.

Menurut Derianto (2001:4), Konsumen yang loyal pada umumnya akan membeli dan mengkonsumsi produk tersebut walaupun dihadapkan pada banyak alternatif merek produk pesaing yang menawarkan karakteristik produk yang lebih unggul dipandang dari berbagai sudutnya. Dipandang dari berbagai sudut atributnya. Bila banyak konsumen dari suatu merek masuk dalam kategori ini, berarti mereka tersebut memiliki ekuitas merek yang kuat. Ekuitas merek adalah seperangkat harta dan hutang merek yang terkait dengan suatu merek, nama, simbol, yang mampu menambah atau mengurangi nilai yang diberikan oleh sebuah produk atau jasa baik pada perusahaan maupun pada pelanggan.

Pengertian ahli diatas dapat diketahui bahwa masing-masing pelanggan atau konsumen mempunya dasar loyalitas yang berbeda tergantung objektifitas masingmasing. Loyalitas dapat didefinisikan sebagai sebuah kecendrungan emosi terhadap sebuah objek, baik berupa sikap suka tidak suka, ingin tidak ingin, hal ini didasarkan oleh pengalaman konsumen sebelumnya ataupun informasi-informasi yang diperoleh konsumen dari sumber lain. Yang kemudian akan mempengaruhi konsumen dalam hal mengevaluasi suatu merk berasarkan kiterika yang relevan yang mengambarkan kegunaan produk bagi konsumen. Kesimpulannya adalah loyalitas membaca adalah ikatan suatu perasaan atau ketergantungan seorang konsumen terhadap keinginan untuk membaca sebuah objek yang dalam hal ini Majalah Gadis, yang mana di dalamnya terdapat keinginan menjaga, memiliki, dan setia pada objek tersebut.

Menurut Derianto (2004:19) indikator dasar loyalitas adalah jumlah konsumen yang bersedia membayar untuk sebuah merk daripada merk yang lain yang menawarkan manfaat sama atau sedikit lebih rendah. Kepuasan menjadi pengukuran pada sebuah bsnis dan loyalitas merupakan akumulasi pengalaman penggunaan produk.

Tingkatan loyalitas terhadap merek dibagi dalam 5 tingkat. Pertama, Switcher/Price Buyer (pembeli yang berpindah-pindah) adalah tingkat loyalitas yang paling dasar. Kedua, Habitual Buyer (Pembeli yang bersifat kebiasaan) : Adalah pembeli yangg tidak mengalami 
ketidakpuasan dalam mengosumsi suatu merek produk. Ketiga, Satisfied Buyer (Pembeli yang puas dengan biaya peralihan) adalah kategori pembeli yang puas dengan merek yang mereka konsumsi. Keempat, Likes The Brand (Menyukasi Merek) ialah kategori pembeli yang benar-benar menyukai merek tersebut. Commited Buyer (Pembeli yang berkomitmen) ialah kategori pembeli yang setia. Mereka mempunyai kebanggaan dalam menggunakan merek.

Menurut Jill Griffin (2002:22) terdapat empat jenis loyalitas yang muncul bila keterikatan rendah dan tinggi diklasifikasisilang dengan pola pembelian ulang, yang rendah dan tinggi.

Adapun jenis-jenis loyalitas konsumen yaitu :

\section{1) Tanpa Loyalitas}

Untuk berbagai alasan tertentu, ada beberapa konsumen yang tidak mengembangkan loyalitas atau kesetiaan kepada suatu produk maupun jasa tertentu. Tingkat keterikatan yang rendah dengan tingkat kosumsi ulang yang rendah menunjukkan absennya suatu kesetiaan. Pada dasarnya, suatu usaha harus menghindari kelompok no loyality ini untuk dijadikan target pasar, karena mereka tidak akan menjadi konsumen yang setia.

2) Loyalitas yang lemah (Inertia Loyality)
Inertia loyality merupakan sebuah jenis loyalitas konsumen yang dimana adanya keterikatan yang rendah dengan kosumsi ulang yang tinggi. Konsumen yang memiliki sikap ini biasanya membeli berdasarkan kebiasaan. Dasar yang digunakan untuk kosumsi produk atau jasa disebabkan oleh faktor kemudahan situsional. Kesetiaan semacam ini biasanya banyak terjadi terhadap produk atau Jasa yangsering dipakai. Contoh dari kesetiaan ini terlihat dari kegiatan kosumsi bensin yang dilakukan konsumen di dekat daerah rumahnya dan sebagainya.

Pembeli dengan loyalitas yang lemah rentan beralih ke produk pesaing yang dapat menunjukkan manfaat yang jelas. Meskipun demikian, perusahaan masih memiliki kemungkinan untuk mengubah jenis loyalitas ini ke dalam bentuk loyalitas yang lebih tinggi melalui pendekatan yang aktif ke pelanggan dan peningkatan nilai perbedaan positif yang diterima konsumen atas produk maupun jasa yang ditawarkan kepadnya dibandingkan dengan yang ditawarkan para pesaing lain. Hal ini dapat dilakukan melalui peningkatan keramahan dalam pelayanan dan fasilitas yang diberikan kepada konsumen.

3) Loyalitas Tersembunyi (Laten Loyality)

Jenis loyalitas tersembunyi merupakan sebuah kesetiaan atau 
keterikatan yang relatif tinggi yang disertai dengan tingkat mengkonsumsi ulang yang rendah. Konsumen yang mempunyai sikap laten loyality kosumsi ulang juga didasarkan pada pengaruh faktor situasional daripada sikapnya. Sebagai contoh, seorang suami menyukai masakan Eropa, tetapi mempunyai istri yang kurang menyukai masakan Eropa. Maka suami tersebut hanya sesekali saja mengunjungi restoran Eropa dan lebih sering pergi ke restoran yang dimana masakan yang ditawarkan dapat dinikmati bersama.

4) Loyalitas Premium (Premium Loyalty)

Loyalitas ini merupakan yang terjadi bilamana suatu tingkat keterikatan tinggi yang berjalan selaras dengan aktivitas kosumsi kembali. Setiap perusahaan tentunya sangat mengharapkan kesetiaan jenis ini dari setiap usaha preference yang tinggi. Contoh jenis loyalty premium adalah rasa bangga yang muncul ketika konsumen menemukan dan menggunakan produk atau jasa tersebut dan dengan senang hati membagi pengetahuan dan merekomendasikannya kepada teman, keluarga maupun orang lain.

Loyalitas pelanggan merupakan ukuran yang dapat diandalkan untuk memprediksi pertumbuhan penjualan dan loyalitas pelanggan juga dapat didefinisikan berdasarkan perilaku pembelian yang konsisten (Griffin, 2002:31). Berikut ini ada lima karakteristik loyalitas konsumen yang perlu diperhatikan yaitu:

a) Melakukan pembelian ulang secara teratur

Konsumen melakukan pembelian dan mengkonsumsi secara contineu pada suatu produk tertentu. Contoh: pencipta motor Harley Davidson akan membeli motor Harley baru jika ada model Harley Davidson yang terbaru, bahkan tidak hanya membeli tetapi mereka juga mengeluarkan uang tambahan untuk mengubahnya sesuai dengan keinginan mereka.

b) Membeli antarlini produk dan jasa

Konsumen tidak hanya membeli dan mengkonsumsi jasa dan produk utama tetapi konsumen juga membeli lini produk dan jasa dari perusahaan yang sama. Contoh: konsumen tidak hanya membeli motor Harley davidson saja, tetapi mereka juga membeli aksesoris dari Harley Davidson untuk mempercantik diri mereka.

c) Mereferensikan kepada orang lain.

Dimana konsumen melakukan komunikasi dari mulut ke mulut (word of mouth) berkenan dengan produk tersebut. Contoh: seorang konsumen Harley Davidson yang sudah lama memakai motor tersebut, menceritakan 
tentang kehebatan dan keunggulan dari motor tersebut, kemudian setelah itu temannya tertarik membeli motor Harley Davidson karena mendengar cerita tersebut.

d) Menunjukkan kekebalan terhadap tarikan dari pesaing.

Konsumen menolak untuk menggunakan produk atau jasa alternatif yang ditawarkan oleh pesaing. Contoh: para pecinta motor Harley Davidson menolak untuk menggunakan motor lain, bahkan mereka juga cenderung menolak untuk mengetahui jenis-jenis motor lainnya. Pelanggan yang loyal merupakan aset bagi perusahaan, hal ini dapat dilihat berdasarkan karateristik yang dimilikinya. Oleh karena itu, loyalitas konsumen merupakan suatu yang bisa diandalkan untuk memprediksi pertumbuhan dimasa yang akan datang bagi suatu perusahaan.

\section{Hubungan Citra Merek dengan Loyalitas}

Konsumen cenderung memilih berdasarkan citra merek, terutama ketika konsumen itu tidak memiliki pengalaman dengan produk dalam kategori tertentu yang tidak pernah mereka beli, mereka akan cenderung untuk "percaya" pada produk dengan nama merek yang terkenal atau favorit. Konsumen sering berpikir bahwa merek yang terkenal merupakan produk yang lebih baik dan lebih bernilai untuk dibeli karena tersirat jaminan akan kualitas, dapat diandalkan, dan pelayanan yang lebih baik. Usaha promosi sebuah merek mendukung pemahaman mengenai kualitas produk mereka dengan membangun dan mempertahankan citra merek yang positif dalam benak konsumen (Schiffman \& Kanuk, 2000:114).

Konsumen sangat jarang hanya melihat dari produk atau jasa itu sendiri, tetapi melihatnya bersama-sama nama merek. Hasilnya, dalam memahami suatu produk atau jasa, persepsi konsumen dibentuk oleh merek. Persepsi konsumen berperan penting dalam pengambilan keputusan pembelian terutama karena apa yang dipahami oleh konsumen lebih penting daripada realitas sebenarnya. Hal inilah yang membuat merek-merek yang dipandang konsumen sebagai terbaik dalam kategorinya adalah merek-merek yang mendulang keuntungan paling banyak, paling dicari konsumen dan memiliki pelanggan dengan loyalitas tinggi (Tybout \& Calkins, 2005:2).

Definisi dari konsumen loyal adalah seseorang yang melakukan aktifitas membeli barang atau jasa yang memenuhi criteria sebagai berikut Melakukan pembelian ulang secara berkala, membeli produk lain yang ditawarkan produsen yang sama, dan merekomendasikan produk tersebut kepada 
orang lain (Griffin,2002:70). Semakin tinggi loyalitas konsumen dan semakin kuat suatu merek, semakin mudah kemungkinan konsumen dapat memaafkan kesalahan yang dilakukan perusahaan. Loyalitas merek dipengaruhi oleh pengalaman penggunaan produk yang memuaskan, citra merek yang positif, atribut merek seperti kualitas, performansi, mempunyai kelebihan yang tidak dimiliki merek lain, harga yang sesuai, ketersediaan dan kemudahan mendapatkan produk merek tersebut. Konsumen yang memiliki loyalitas terhadap suatu merek akan terus melakukan pembelian ulang terhadap merek tersebut, tidak mudah untuk tergiur dengan promosi dari pihak pesaing dan adanya kemauan untuk merekomendasikan merek tersebut kepada orang lain.

Dalam penelitian ini, teori yang melandasi hubungan citra merek Majalah Gadis dengan loyalitas membaca adalah Expectancy Value Theory oleh Phillip Palmgreen (Littlejohn, 2009 : 426). Expectancy Value Theory menyatakan bahwa perilaku seseorang merupakan fungsi nilai (value) dari hasil yang diharapkan dari sebuah perbuatan. Perilaku seseorang akan menghasilkan sesuatu, semakin tinggi nilai yang diharapkan, semakin tinggi pula keinginan untuk mewujudkan perilaku tertentu. Teori memiliki tiga komponen dasar yakni: Individu merespon informasi baru tentang suatu hal atau tindakan dengan

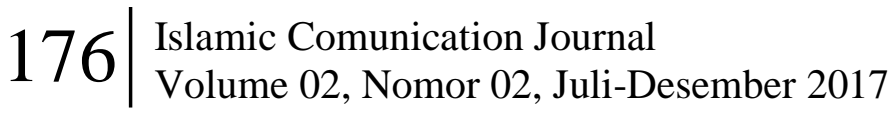

menghasilkan suatu keyakinan dari hal atau tindakan tersebut. Setiap individu memberikan sebuah nilai (value) pada setiap sifat dimana keyakinan tersebut terbentuk. Sebuah harapan (expectation) terbentuk atau termodifikasi berdasarkan hasil perhitungan antara keyakinan (beliefs) dan nilai-nilai (value). (Klandersman, 1997:26).

Dalam teori ini, Palmgreen menyatakan ketika seorang individu memperoleh pengalaman yang positif dengan sebuah hal (produk, media, genre, program), kepuasan individu yang didapat setelahnya akan mempengaruhi keyakinan individu tentang hal tersebut, juga menguatkan pola penggunaan terhadap hal tersebut (Littlejohn, 2009 : 427). Kepuasan yang dicari individu dari media ditentukan oleh sikap individu terhadap media. Keyakinan individu tentang media tertentu yang dapat memberikan kepuasaan kepada individu, dan bagaimana penilaian material tentang media tersebut.

Expectancy Value Theory ialah satu dari beragam Teori Komunikasi Massa yang meneliti pengaruh penggunaan media oleh khalayak dilihat dari penggunaannya. Teori ini mengemukakan bahwa sikap seseorang terhadap segmensegmen media ditentukan oleh nilai yang mereka percaya dan evaluasi mereka mengenai media tersebut. Dalam hubungannya dengan penelitian ini, 


\section{Ahmad Khairul Nuzuli}

Ketika konsumen Majalah Gadis, membeli kemudian membaca Gadis dikarenakan konsumen Majalah Gadis menginginkan info baru mengenai style dan fashion, dengan begitu keinginan akan hal tersebut terpenuhi. Keinginan tersebut sesuai dengan kepentingan konsumen Majalah Gadis.

Teori ini dalam kaitannya dengan loyalitas membaca majalah gadis adalah ketika pembaca telah membaca Majalah Gadis maka ia telah tahu nilai-nilai yang terkandung dalam majalah gadis. Pembaca mampu memberikan penilaian mengenai majalah gadis, apabila hal tersebut sudah seusai dengan harapannya maka ada kemungkinan ia akan melakukan pembelian ulang. Sudah terbentuk keyakinan bahwa terbitan-terbitan Majalah Gadis selanjutnya tidak akan mengecewakan atau sesuai dengan harapannya.

Kepuasan pembaca Majalah Gadis atas apa yang telah diberikan Majalah Gadis akan mempengaruhi keyakinan individu tentang kekuatan merek Majalah Gadis, hal ini ternyata menguatkan pula pola penggunaan terhadap suatu hal, pola penggunaan apabila dikaitkan dengan penelitian ini adalah loyalitas pembaca Majalah Gadis dalam mempergunakan produk atau membaca Majalah Gadis.
Lebih lanjut, kepuasan yang didapat individu bisa didasarkan pada pengalaman positif yang didapat individu akan suatu hal, dalam hal ini pengalaman positif yang di dapat pembaca Majalah Gadis ketika membaca majalah tersebut akan menimbulkan citra merek yang positif pula pada benak mereka. Maka dari itu, kepuasan pembaca terhadap Majalah Gadis akan memunculkan citra merek yang positif tentang Majalah Gadis, hal ini menimbulkan tindakan berkelanjutan yaitu dengan sikap pembaca untuk terus membaca Majalah Gadis dengan loyalitas yang tinggi.

\section{Metodologi Penelitian}

\subsection{Jenis Penelitian}

Penelitian ini digolongkan dalam jenis penelitian Eksplanatif atau Eksplanatori, yakni penelitian yang bertujuan untuk menjelaskan hubungan kausal antar variabel-variabel melalui pengujian hipotesa, kemudian menjelaskan hubungan antar variabel atau menyusun hipotesis tentang hubungan variabel itu dan mengujinya apakah ada hubungan yang signifikan atau tidak.

\subsection{Populasi dan Sampel}

Populasi dalam penelitian ini adalah remaja perempuan pembaca Majalah Gadis di Kota Semarang, usia 15-17 tahun. Penelitian ini memilih rentang usia tersebut 
dikarenakan topik penelitian ini ialah Majalah Gadis, yang memiliki target pembaca remaja perempuan dengan kisaran usia tersebut. Populasi dalam penelitian ini tidak diketahui jumlahnya, karena tidak memiliki acuan atau daftar data yang pasti dan tidak memiliki informasi yang lengkap mengenai ukuran populasi.

Penelitian ini menggunakan teknik multistage random sampling Terdapat 8 SMA dengan SES A-B di Kota Semarang yaitu untuk SMA Negeri antara lain SMAN 3 Semarang, SMAN 1 Semarang, SMAN 4 Semarang, dan SMAN 5 Semarang. Untuk SMA Swasta antara lain SMA Kolese Loyola, SMA Semesta Bilingual Boarding School, SMA Karang Turi, dan SMA Sedes Sapientiae. Berdasarkan hasil undian, dari delapan sekolah terpilih satu sekolah yaitu SMAN 1 Semarang.

Pada penelitian ini yang termasuk dalam sampel adalah Siswi SMAN 1 Semarang, kelas 10 yang diketahui membaca Majalah Gadis. Jumlah populasi kelas 10 dan kelas 11 adalah 425 Siswa. Untuk menentukan sampel dalam penelitan ini menggunakan rumus Slovin:

$$
\mathrm{N}=\mathrm{n} / \mathrm{N}(\mathrm{d}) 2+1
$$

Keterangan: $\mathrm{n}=$ sampel; $\mathrm{N}=$ populasi; $\mathrm{d}$ $=$ nilai presisi $95 \%$ atau sig. $=0,05$.
Dari penghitungan menggunakan rumus Slovin, maka didapat jumlah sampel dalam penelitian ini sejumlah 136 siswa

\section{4 Teknik Analisis Data}

Metode analisis data yang digunakan dalam penelitian ini adalah metode analisis bivariate, dimana analisis dilakukan untuk menguji dan membuktikan adanya hubungan antara dua variabel. (Lind, 2011:128) Dua variabel dalam penelitian ini adalah Citra Merek Majalah Gadis dan Loyalitas Membaca Majalah Gadis di Kota Semarang.

Adapun alat uji statistik yang digunakan dalam penelitian ini adalah Korelasi Kendall's Tau B. Hal ini disebabkan karena kedua variabel dalam penelitian ini memiliki data yang berskala berbeda yaitu ordinal dan rasio menggunakan bantuan program Statistical Product and Service Solution (SPSS).Guna mengetahui apakah variabel yang diuji signifikan atau tidak, hasil korelasi akan menunjukan signifikansi ketika dibandingkan dengan angka kritik tabel korelasi dengan taraf signifikan 0,05 atau 5\%. Jika signifikansi dari hasil perhitungan korelasi lebih besar dibandingkan nilai kritis, maka dinyatakan sebagai Ho (hipotesis-o) diterima dimana tidak ada hubungan atau tidak ada korelasi antar kedua variabel dalam penelitian ini. Sebaliknya signifikansi dari hasil perhitungan korelasi lebih kecil dibanding nilai kritis, maka dinyatakan 
sebagai Ho (hipotesis-o) ditolak dimana terdapat hubungan atau korelasi antar kedua variabel dalam penelitian ini. (Santoso, SPSS Mengolah Data Statistik Secara Profesional, 2000 : 291).

\subsection{Definisi Konsepsional Dan Definisi Operasional}

\subsubsection{Citra Merk Majalah Gadis}

Citra merek Majalah Gadis adalah kumpulan persepsi tentang Majalah Gadis yang saling berkaitan serta berada dalam benak serta pemikiran pembaca Majalah Gadis.Citra merek yang positif atau negatif terjadi ketika konsumen memberikan reaksi yang baik atau kurang baik terhadap atribut tertentu dari suatu merek.

Berdasarkan pada tiga unsur citra merek menurut Keller yaitu attributes, benefits dan brand attitude, maka indikator yang digunakan untuk mengukur Citra Merek Majalah Gadis adalah:

Attributes, hal-hal yang berkaitan dengan merek :

- Menilai tampilan visual Majalah Gadis, yaitu cover, layout, dan backcover.

- Menilai macam-macam artikel dan rubrik yang ada di Majalah Gadis.

- Menilai event-event dari Majalah Gadis.

Benefits, keuntungan atau nilai yang dikaitkan dengan suatu merek oleh konsumen

- Menilai jenis-jenis bonus atau hadiah yang berasal dari Majalah Gadis.

- Menilai manfaat setelah membaca artikel atau rubrik Majalah Gadis.

- Menilai manfaat dari Bonus yang diberikan Majalah Gadis.

- Menilai manfaat dan respon dari mengikuti event yang diadakan oleh Majalah Gadis.

Brand attitude, evalusasi suatu merek yaitu apa yang dipercayai oleh konsumen mengenai merek-merek tertentu :

- Menilai perbandingan antara Majalah Gadis dengan majalah remaja lain, dari segi tampilan visual, rubrik dan artikel, bonus, serta event yang diadakan.

\subsubsection{Loyalitas membaca Majalah} Gadis di Kota Semarang

Loyalitas membaca Majalah Gadis di Kota Semarang adalah kecenderungan pembaca majalah Gadis untuk melakukan pembelian ulang majalah Gadis dikarenakan kepuasan pembaca yang didapat dari Majalah Gadis di Kota Semarang. Loyalitas membaca majalah Gadis indikator yang digunakan antara lain: 
- Mengetahui keberadaan Majalah Gadis

- Melakukan pembacaan ulang pada edisi Majalah Gadis periode mendatang.

- Membaca Majalah Gadis dengan frekuensi yang tinggi setiap kali terbit, pada periode satu bulan secara rutin.

- Merekomendasikan Majalah Gadis pada teman, keluarga, atau kerabat terdekat.

\section{PEMBAHASAN}

Dari hasil tabel Korelasi Kendall's Tau B nilai signifikansi sebesar 0.018 atau lebih kecil dari angka kritis yaitu 0.05. Sehingga terdapat korelasi antara kedua variabel dalam penelitian ini dengan menunjukkan hasil yang signifikan. Artinya terdapat hubungan antara Citra merek majalah gadis dan loyalitas membaca majalah gadis di Kota Semarang. hal ini selaras dengan teory Expectancy Value Theory oleh Phillip Palmgreen (Littlejohn, 2009 : 426).
Expectancy Value Theory menyatakan bahwa perilaku seseorang merupakan fungsi nilai (value) dari hasil yang diharapkan dari sebuah perbuatan. Perilaku seseorang akan menghasilkan sesuatu, semakin tinggi nilai yang diharapkan, semakin tinggi pula keinginan untuk mewujudkan perilaku tertentu. Teori memiliki tiga komponen dasar yakni: Individu merespon informasi baru tentang suatu hal atau tindakan dengan menghasilkan suatu keyakinan dari hal atau tindakan tersebut. Setiap individu memberikan sebuah nilai (value) pada setiap sifat dimana keyakinan tersebut terbentuk. Sebuah harapan (expectation) terbentuk atau termodifikasi berdasarkan hasil perhitungan antara keyakinan (beliefs) dan nilai-nilai (value). (Klandersman, 1997:26). Expectancy Value Theory yang dalam penelitian ini dikaitkan dengan konteks citra Majalah gadis nilai dan Loyalitas Membaca sebagai wujud perilaku yang dipengaruhi nilai. Untuk mengetahui nilai koefisien korelasi, dapat dilihat pada tabel 1,2 berikut ini :

Tabel 1.2 Tabel Koefisien Korelasi

\begin{tabular}{|c|l|}
\hline Nilai Koefisien Korelasi & \multicolumn{1}{|c|}{ Keterangan } \\
\hline Kurang dari 0.20 & Hubungan rendah sekali \\
\hline $0.20-0.39$ & Hubungan rendah tetapi pasti \\
\hline $0.40-0.70$ & Hubungan yang cukup berarti \\
\hline $0.71-0.90$ & Hubungan yang tinggi; kuat \\
\hline Lebih dari 0.90 & Hubungan yang sangat tinggi; kuat sekali; dapat diandalkan \\
\hline
\end{tabular}

$180 \mid \begin{aligned} & \text { Islamic Comunication Journal } \\ & \text { Volume 02, Nomor 02, Juli-Desember } 2017\end{aligned}$ 
Sumber : Kriantono (2008: 171)

Jika dilihat dari Tabel Koefisien Korelasi diperoleh hasil 1.0. Jika dilihat dari table korelasi maka dapat diketahui bahwa hubungan sangat tinggi.

Menurut Rakhmat (2013 : 222) Citra terbentuk berdasarkan informasi yang diterima. Masyarakat yang menerima informasi akan memberikan citra pada Majalah Gadis dengan harapan ini akan mempengaruhi loyalitas membaca majalah gadis di Kota Semarang. Dengan kata lain loyalitas membaca majalah gadis di Kota Semarang muncul ketika citra Merk Majalah positif dimata masyarakat.

Hasil deskrispsi mengenai perbandingan Majalah gadis dengan majalah remaja lain juga mendukung pernyataan majalah gadis lebih unggul terutama dari segi manfaat yang diberikan melalui bonus dan acara yang diadakan. Maka dari itu, citra merek majalah gadis yang sudah sangat baik belum tentu akan membuat masyarakat akan loyal ketika membacanya.

\section{PENUTUP}

Adanya hubungan yang signifikan antara citra merek Majalah Gadis dengan loyalitas membaca Majalah Gadis di Kota Semarang. Dan hubungannya sangat tinggi.

Setelah ditarik kesimpulan sebagaimana yang kami tulis diatas, penelitian ini kemudian diharapkan dapat memberikan beberapa alternatif saran yang mungkin bermanfaat kelak bagi media massa maupun pengetahuan bagi khalayak pada umumnya. Uraiannya adalah sebagai berikut:

1. Jenis huruf pada bagian sampul depan atai cover dibuat lebih sederhana dan mempergunakan font yang mudah dibaca.

2. Tulisan-tulisan yang terdapat pada sampul depan ditata secara sistematis dengan tidak menumpuk huruf, ilustrasi, dan background dengan warna yang senada karena tidak akan terbaca

3. Mengurangi pengunaan dominasi warna merah muda, biru, maupun warna cerah lainnya, pergunakan pula warna-warna yang netral seperti abuabu, putih, hitam, maupun warnawarna pastel

\section{DAFTAR PUSTAKA}

Alma, Buchari. 2005. Manajemen Pemasaran dan Manajemen Pemasaran Jasa; Edisi 2. Bandung: Alfabeta.

Arafah, Willy. 2004. Analisis Kualitas Pelayanan Rumah Sakit Terhadap Image (Studi pada Rumah Sakit pemerintah “ $X$ " di Jakarta Selatan). Metode Riset bisnis dan Manajemen. Volume 4. No.1.April: 55-75. 
Hubungan Citra Merek Majalah Gadis... hal. 162-183

Derianto, dkk. 2004. Brand Equity Ten Strategi Memimpin Pasar, Jakarta : Gramedia Pustaka Utama

Diah, Wardhani. 2008.Media Relations : Sarana Membangun Reputasi Organisasi. Graha Ilmu, yogyakarta : 2008

Danang Sunyoto. 2012. Dasar-dasar manajemen pemasaran. Cetakan Pertama. Yogyakarta : CAPS.

Fandy, Tjiptono.2011. Pemasaran Jasa, Bayumedia, Malang.

Fandy, Tjiptono, 2004, Strategi Pemasaran, edisi kedua, Andi,. Yogyakarta.

Griffin, Hill. 2002. Customer Loyalty, How to Earn it How to Keep it. Loxington: Books An Imprint of The Free Press.

Hasan, Ali. 2008. Marketing. Yogyakarta : Media Utama.

Hartimbul Ginting, Nembah F. 2011.

Manajemen Pemasaran. Bandung: CV.

Yrama Widya

Hermawan Kartajaya. 2003. Marketing In

Venus. Jakarta: Gramedia Pustaka Utama

Klandermans, Elie. 1997. The Social Psychology of Protest. Cambridge, Massachusetts: Blackwell Publishers

Kotler, Philip, dan Kevin Lane Keller. 2009. Manajemen Pemasaran Jilid

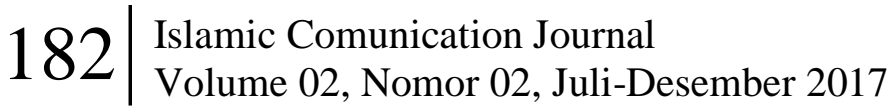

1, edisi Ketiga Belas; terjemahan Bob Sabran, MM. Jakarta: Erlangga Kotler, Philip. 2005. Manajamen Pemasaran, Jilid 1 dan 2. Jakarta: PT. Indeks Kelompok Gramedia. Kriyantono, Rakhmat .2008. Tenik Praktis Riset Komunikasi.Jakarta : Prenada Media Group.

Littlejohn, Stephen W dan Karen A. Foss. 2009. Teori Komunikasi; Theories of Human Communication; Edisi 9. Jakarta: Salemba Humanika

Lind, Douglass A.,Marchal, William G.,Wathen, Samuel A. 2011. Teknik-teknik STATISTIKA dalam BISNIS DAN EKONOMI Menggunakan Kelompok Data Global, Edisi Tiga Belas. Jakarta: Salemba Empat

Rakhmat, J.2013. Psikologi Komunikasi. Bandung : PT Remaja Rosdakarya. Rangkuti, Freddy.2002. Measuring Customer Satisfaction, Penerbit PT Gramedia Pustaka Utama, Jakarta Santoso, Singgih. 2014. SPSS 22 from Essential to Expert Skills, Gramedia anggota IKAPI, Jakarta. Schiffman, Leon, Leslie Lazar Kanuk. 2000. Consumer Behaviour. Seventh Edition. Prentice Hall International, Inc, New Jersey.

Shimp, Terence A. 2003. Periklanan

Promosi dan Aspek Tambahan 
Komunikasi Pemasaran Terpadu,

Jilid I, Edisi Kelima. Alih Bahasa

Revjani Sjahrial \& Dyah Anikasari.

Jakarta : Erlangga.

Sutisna. 2003. Perilaku Konsumen dan Komunikasi Pemasaran. Bandung:

PT. Remaja Rosdakarya Offset.

Suryani, Tatik. 2008. Perilaku Konsumen:

Implikasi pada Strategi Pemasaran.

Edisi 1. Yogyakarta: Graha Ilmu.

Tybout, A. M. Calkins. 2005. Kellog On

Branding. Jakarta: PT.

Prenhallindo 